\title{
PHYTOCHEMICAL EVALUATION AND ANTIOXIDANT SCREENING STUDIES OF OCIMUM TENUIFLORUM LINN SEEDS
}

\author{
JYOTSANA SHARMA ${ }^{1 *}$, NAVNEET KHURANA ${ }^{1}$, NEHA SHARMA ${ }^{1}$, RAKESH GARG ${ }^{2}$ \\ ${ }^{1}$ Department of Pharmacognosy, School of Pharmaceutical Sciences, Lovely Professional University, Phagwara, Punjab, India. \\ ${ }^{2}$ Department of Pharmacognosy, S.D. College of Pharmacy, Barnala, Punjab, India. Email: jyotsanasharma02@gmail.com
}

Received: 14 July 2017, Revised and Accepted: 25 July 2017

\section{ABSTRACT}

Objective: In the existing study, Ocimum tenuiflorum was assessed for its antioxidant activity. This activity was assessed using the 2,2-diphenyl-1picrylhydrazyl (DPPH) method. The drug was identified and standardized on the basis of organoleptic, negligible characters and its quantitative physicochemical standards.

Methods: Preliminary phytochemical screening was also carried out to examine out the presence of various phytoconstituents. It revealed the presence of alkaloids, phytosterols, resin, flavonoids, tannins, diterpenes, and protein in the seed extract. DPPH method was done used for evaluating the antioxidant activity.

Results: It has been observed that different concentrations $(100,200,300,400$, and $500 \mu \mathrm{g} / \mathrm{mL})$ used had shown $82.1 \%, 83.4 \%, 86.6 \%$, 89.1\%, and $93.2 \%$ of cell inhibition, respectively.

Conclusion: Thus, the present study on pharmacognostic standardization, physicochemical evaluation and in vitro antioxidant activity of 0 . tenuiflorum seed would be useful to supplement information in regard to its in vivo evaluation for different pathological conditions.

Keywords: Ocimum tenuiflorum, Lamiaceae, Standardization, Phytochemical screening, Antioxidant.

(C) 2017 The Authors. Published by Innovare Academic Sciences PvtLtd. This is an open access article under the CC BY license (http://creativecommons. org/licenses/by/4. 0/) DOI: http://dx.doi.org/10.22159/ajpcr.2017.v10s4.21341

\section{INTRODUCTION}

Herbal plants or Folk medicines have been long used as a medication since classical times for the treatment of the majority of diseases. Folk plants used to enact a very significant role in world health [1,2]. For this World Health Organization (WHO) recognized the requirement of evenness and high content of herbal drugs [3]. WHO had fixed certain parameters for explaining the basic criteria for the evaluation of quality, safety and efficacy of herbal remedies. Since herbal drugs have gained momentum, so the standardization of herbal drugs is most desirable at this moment. Morphological characters such as organoleptic characters, arrangement of leaflets, venation, texture, surface characters, markings, and hardness of the plant materials.

Tulsi itself is originated from Sanskrit language which means "matchless one $[4,5]$." This is considered as popular basil and is placed at the top of herbs because it is excessively used to its economic, nutritional and medicinal properties. Volatile oil such as monoterpenes, sesquiterpenes, and aromatic constituents had been reported in the fixed oil obtained from the leaves of the plant [6]. Monoterpenes such as camphene, sabinene, and myrcene have been reported. Oxygen containing monoterpenes such as linalool. Borneol, terpin-4-ol was also extracted out from the oil of the leaf. Other sesquiterpene reported in the oil of leaf are $\alpha$-copanene, $\alpha$-caryophyllene, etc., aromatic compounds such as estragole, thymol, and carvacrol were also present in the oil of the tulsi plant.

Various phytochemical presents in the tulsi plant are as follows:

\begin{tabular}{lll}
\hline Extract & Phytochemicals & $\begin{array}{l}\text { Plant } \\
\text { part }\end{array}$ \\
\hline Fixed oil [7] & $\begin{array}{l}\text { Linoleic acid, oleic acid, and stearic } \\
\text { acid }\end{array}$ & $\begin{array}{l}\text { Seeds of } \\
\text { the plant }\end{array}$ \\
\hline
\end{tabular}

\begin{tabular}{lll}
\hline $\begin{array}{l}\text { Essential } \\
\text { oil [8-10] }\end{array}$ & $\begin{array}{l}\text { Aromadendrene oxide, benzaldehyde, } \\
\text { borneol, bornyl acetate, camphor, } \\
\text { cubenol, d-limonene, eicosane, } \\
\text { eucalyptol, eugenol, farnesene, }\end{array}$ & Leaves \\
& $\begin{array}{l}\text { limonene, n-butylbenzoate, ocimene, } \\
\text { oleic acid, cadinene, humulene }\end{array}$ & \\
Mineral & Vitamin C, Vitamin A, calcium, & Whole \\
contents [11] & phosphorus & plant \\
Alcoholic & $\begin{array}{l}\text { Aesculetin, apgenin, caffeic acid, } \\
\text { extracts [12] }\end{array}$ & Alorogenic acid, circineol, isovitexin, \\
& $\begin{array}{l}\text { luteolin, molludistin, orientin, } \\
\text { protocatechuic acid, stigmasterol, }\end{array}$ & \\
& ursolic acid, vallinin, viceni, vitexin, & \\
& vllinin acid & \\
\hline
\end{tabular}

The oil extracted from the plant exhibit various biological activities such as antidiabetic [13], antihypotensive [14], anticonvulsant [15], antioxidant activity [16], anthelmintic [17], muscle relaxant [18], antibacterial, and anticarcinogenesis $[19,20]$. Other reported direct usage of the plant parts such as leaves for the healing of headache [21], eye disorders [22], healing power [23], anti-inflammatory [24], and skin disorders such as insect bites, pimples [25-27], and teeth disorder [28]. Even the tulsi plant is of huge advantage that it can be even used for the treatment of stress [29] and heart diseases [30].

Ethanolic extract of Ocimum species found to be potent in showing antimetastatic activity and in boosting antioxidant enzyme activity. Many herbs mentioned in Ayurveda for the treatment of tumors including cancer therapy and are also capable of preventing the side effects with the complete healing power [31,32]. Oxidative phosphorylation may cause the emergence of reactive oxygen species (ROS) that can destroy cellular DNA and other natural proteins. Higher amount of ROS may break double stranded DNA and causes the ageing 
of the cell, cardiac disorders, mutation with in the cells, and cancerous cell growth $[33,34]$.

\section{METHODS}

Collection and authentication of seeds of Ocimum tenuiflorum (Linn.)

The 0 . tenuiflorum (Linn.) seeds were procured from the Central Institute of Medicine and Aromatic Plant Lucknow near Kukrail Picnic Spot Lucknow. The Herbal plant was examined and authenticated by Dr. Amardeep Kaur, Lecturer in Botany at S.D. College Barnala. After authentication, plant materials were cleaned (hand picking and winnowing methods) and dried under shade at room temperature.

\section{Macroscopic evaluation of seeds of $\boldsymbol{O}$. tenuiflorum (Linn.)}

The macroscopic characters such as expansion, appearance, shade, and flavor of seeds of 0 . tenuiflorum (Linn.) were determined [35]

\section{Physicochemical evaluation of seeds of $O$. tenuiflorum (Linn.)}

Determination of ash values of seeds of O. tenuiflorum (Linn.)

Residue left after the complete burning of the crude drug is known as ash. Determination of ash value is important for evaluating grade and contamination of the folk drug. It detects the fact of occurring inorganic matter such as metallic salts, ions, silica content, and earthy materials such as sand, pebbles, and minerals [36,37].

- Determination of total ash

Specifically weighed $3 \mathrm{~g}$ of drug dried in atmospheric air was retained in a pre-ignited and weighed silica crucible. The granules of drug were layered in the crucible and incinerated in the muffle furnace by slowly evaluating the temperature to make it complete white free from traces of carbon. Then, crucible was kept out in air to cool down, weighed, and the steps were recapitulated till a steady weight was obtained.

- Determination of acid insoluble ash

Total ash boiled with $25 \mathrm{~mL}$ of $2 \mathrm{M} \mathrm{HCl}$ for 4-5 minutes. The matter which was not dissolved was deposited on ash less filter paper, followed by the washing with hot water. Transfer that insoluble ash to the preweighed silica crucible, incinerate it, cool it and measure its weighed. The steps were again followed till a fixed weight was obtained.

- Determination of water soluble ash

Total ash was bubbled with $25 \mathrm{~mL}$ of water for 4-5 minutes. Undissolved matter was gathered on ash less Whatman filter paper and rinse with little warm water. Place filter paper with insoluble ash in a crucible and allow to getting completely burn within 15 minutes at a temperature of $450^{\circ} \mathrm{C}$ and weighing it. Mass of undissolved matter was deducted from the weight of total ash obtained. The variation obtained represents water soluble ash.

Determination of solvent extractive values of seeds of o. tenuiflorum (Linn.)

\section{- Determination of water soluble extractive value}

About $5 \mathrm{~g}$ of powdered drug was taken in a conical flask, fitted with a cork, to that $100 \mathrm{~mL}$ of chloroform was added and shaken regularly for 6-7 hrs using an electrical shaker and then allow for maceration for next $18 \mathrm{hrs}$. Filtered it carefully and small amount of filtrate was heated to dryness at a temperature of $105^{\circ} \mathrm{C}$ in a small china dish. The extract was weighed, and percentage was calculated with reference to air dried drug.

- Determination of alcohol soluble extractive value

About $5 \mathrm{~g}$ of correctly measured air-dried powdered drug was macerated with $100 \mathrm{ml}$ of $90 \%$ alcohol for $24 \mathrm{hrs}$. It was shaken constantly for $6 \mathrm{hrs}$ in an electrical shaker and kept constant for next $18 \mathrm{hrs}$. Filter it carefully so that there should be any loss of alcohol and $30 \mathrm{~mL}$ of the filtrate was evaporated to dryness at a temperature $105^{\circ} \mathrm{C}$ in a tarred flat-bottomed shallow china dish. Weight of extract was taken, and percentage was calculated.
- Determination of ether soluble extractive value About $5 \mathrm{~g}$ of weighed granular drug was placed in a conical flask fitted with a stopper. To that $100 \mathrm{~mL}$ of petroleum ether was added. Using electrical shaker, shake it for 6-7 hrs and keep them undisturbed for next $18 \mathrm{hrs}$ for maceration. Filter it properly so that there should not be any loss of petroleum ether and evaporate it to dryness in a flat bottomed china dish. Weight of extract was taken, and percentage was calculated.

\section{Determination of moisture content of seeds of 0 . tenuiflorum (Linn.)}

Accurately weighed quantity of drug was taken into tarred crucible, crucible was covered, and crucible and the contents were weighed. Loaded silica crucible was placed in a hot air oven at $105^{\circ} \mathrm{C}$, and the cover was removed and left in chamber. Sample was dried to a fixed weight. Moisture content of sample was calculated with reference to the air-dried drug.

\section{Determination offoreign organic matter of seeds of O. tenuiflorum} (Linn.)

Accurately weigh $10 \mathrm{~g}$ of sample and spread it equally on a white paper without overhanging. Inspect the sample using $\times 5$ lens and separate out foreign matter, if found. Once separation was completed, weigh the matter and calculate percentage $\mathrm{w} / \mathrm{w}$ of foreign organic matter.

Determination of swelling index of seeds of O. tenuiflorum (Linn.) To evaluate the swelling behavior, $1 \mathrm{~g}$ of the seeds of $O$. tenuiflorum (Linn.) was taken in a $100 \mathrm{~mL}$ measuring cylinder with graduated readings in it. Initial volume occupied by seeds was noted. In addition to this, add $2 \mathrm{~mL}$ of alcohol for better dispersion and then add sufficient quantity of water to make up the volume up to $100 \mathrm{~mL}$. The measuring cylinder was kept at a room temperature, and swollen mass of seeds was noted after $24 \mathrm{hrs}$.

Phytochemical screening of seeds of $O$. tenuiflorum (Linn.)

Various extracts, viz., hexane, chloroform, ethyl acetate, and methanol extracts were prepared by hot percolation process for preliminary phytochemical screening. Identification tests were carried out for these extracts to detect various phytoconstituents such as alkaloids (Mayer's test, Wagner's test, Dragendroff's test, and Hager's test), saponins (Foam test), tannins (lead acetate, ferric chloride test, and Potassium dichromate test), phytosterols (Salkowski test, Libermann's test, and Liebermann-Burchard's test), phenols (ferric chloride test), proteins (Biuret test), flavonoids (Shinoda test, alkaline reagent test, and lead acetate test), triterpenoids (Liebermann-Burchard's test), carbohydrates (Molisch's test, Barfoed's test, and Fehling solution test) amino acids (Ninhydrin test, and Xanthoproteic test) in the seeds of O. tenuiflorum (Linn) [38].

\section{Test for steroids}

a. Salkowaski reaction

Few drops of the extract were taken in a test tube, to that $1-2 \mathrm{~mL}$ of chloroform was added, $2 \mathrm{~mL}$ of sulfuric acid was added by the side of the test tube. Shake it for 2-3 minutes and if there is the formation of red color that may indicate the presence of steroids in the given sample.

b. Libermann's test

To a few drops of extract in a test tube, $2 \mathrm{ml}$ of acetic anhydride was added, and a gentle heating was given to the test tube. Then, cool down the content of the test tube. On addition of few drops of sulfuric acid by the side of the test tube, if there is the appearance of blue color that would indicate the presence of sterol in the sample.

c. Liebermann-Burchard's reaction

Few drops of the extract were taken in test tube, to that $1 \mathrm{~mL}$ of chloroform was added, followed by addition of acetic anhydride. On addition of sulfuric acid to test tube, a transient color develops 
from red to blue and finally to green. And that is the indication for the presence of sterol in the sample.

\section{Test for alkaloids}

Few $\mathrm{mg}$ of extract was taken separately in $5 \mathrm{ml}$ of $1.5 \% \mathrm{v} / \mathrm{v}$ hydrochloric acid and filtered. These filtrates were then subjected to various tests for confirmation of the presence of alkaloidal content within the extracts.

a. Mayer's test

To the filtrate, on addition of potassium mercuric iodide, if there is formation of cream colored precipitate that would reflect the presence of alkaloids in the sample.

b. Wagner's test

On the treatment of filtrate with iodine in potassium iodide, if there is formation of brown/reddish precipitate that would depict the presence of alkaloids in the sample.

c. Dragendroff's test

When filtrate was treated with a solution of potassium bismuth iodide, and if there is formation of red precipitate that would signify the presence of alkaloids in the sample.

d. Hager's test

On treatment of filtrate with saturated picric acid solution, if there is formation of yellow colored precipitate that would display the presence of alkaloids in the sample.

\section{Tests for tannins}

The extract was taken in water, warmed, and filtered. Tests were carried out with the filtrate using following reagents to find weather the extract was found to be positive for tannin content or not.

a. Ferric chloride reagent

To the filtrate, $5 \% \mathrm{w} / \mathrm{v}$ ferric chloride in $90 \%$ alcohol was added. If in the solution shows there is appearance of dark green or deep blue color that indicates the presence of tannins.

b. Lead acetate test

To the filtrate, add $10 \% \mathrm{w} / \mathrm{v}$ solution of lead acetate, if there is formation of precipitate that would suggest the presence of tannins.

c. Gelatin solution test

Solution of $1 \%$ gelatin in $10 \%$ sodium chloride was prepared. To this a few $\mathrm{mL}$ of filtrate was added, and if there was formation of a white precipitate that would reflect the presence of tannins in the given sample.

d. Bromine water test

On addition of bromine to filtrate, if decolorization of bromine water occurs that would convey the presence of tannins in the given sample.

Test for flavonoids

a. Shinoda test

Few mg of extract was dissolved in $5 \mathrm{~mL}$ of ethanol and to that 2-3 drops of hydrochloric acid was added. To the above $0.5 \mathrm{~g}$ of magnesium metal was also added. Development of pink or magenta color would manifested the flavonoids in the sample.

b. Alkaline reagent test

Treat the extract with few drops of sodium hydroxide solution which leads to the formation of yellow color solution, which on addition of dilute acid, become colorless, reflects the existence of flavonoids.

c. Lead acetate test

On treatment of the extract with lead acetate solution, if there is formation of a yellow color precipitate that would vision the presence of flavonoids in the sample.

Test for amino acids

a. Ninhydrin test

To the extract add $0.25 \% \mathrm{w} / \mathrm{v}$ ninhydrin reagent and allow it to boil for 5-6 minutes. If there is formation of blue color precipitate that would suggest the presence of amino acid. b. Xanthoproteic test

When the extract was treated with few drops of concentrations nitric acid, and if there is formation of a yellow color precipitate that would evident the presence of proteins.

c. Biuret test

When the equal volume of sodium hydroxide and copper sulfate was added to the extract, and there is appearance of pink or purple color that would imply the presence of amino acid in the sample.

Test for sugars

- Molisch's test

To the extract add small amount of water and add few drops of Molisch reagent to that add sulfuric acid by the side of the test tube, if there is appearance of brown ring at the interface of two liquids that would point out the presence of sugars in the sample.

- Barfoed's test

To the test sample add few drops of Barfoed's reagent and allow it to boil for some time. If by that time there is appearance of a red precipitate of cuprous oxide within that would declare the presence of monosaccharides.

- Fehling's solution test

Both the solution, i.e., Fehling's A and Fehling's B were added to the extract in equal amount, and the extract was allowed to boil for some time if there was formation of a red precipitate of cuprous oxide recommended the presence of reducing sugar.

\section{Test for saponins}

- Foam test

Few ml of extract was taken in the graduated measuring cylinder, dilute it with water and then carried agitation for 15 minutes. If there formation of $1 \mathrm{~cm}$ layer of foam that would indicate the presence of saponins.

\section{Extraction of mucilage from seeds of 0 . tenuiflorum (Linn.)}

The crushed powder of seeds was dissolved in distilled water. The inflated mass of seeds was spread on to a glass tray and was dried at $60^{\circ} \mathrm{C}$. Allowed to pass that material from mesh \#30. Then winnowing was done after that passes that material from mesh \#60. The mucilage obtained at this point was weighed [39].

Organoleptic characters of mucilage extracted from seeds of o. tenuiflorum (Linn.)

Organoleptic characters of mucilage extracted from seeds of O. tenuiflorum (Linn.) such as appearance, color, odor, and taste were determined by standard methods.

\begin{tabular}{ll}
\hline Physicochemical parameters & Results \\
\hline Appearance & Amorphous \\
Color & Brown \\
Odor & Odorless \\
Taste & Mucilaginous \\
\hline
\end{tabular}

Physicochemical evaluation of mucilage of seeds of $\boldsymbol{O}$. tenuiflorum (Linn.)

For physicochemical evaluation of mucilage of seeds of 0 . tenuiflorum (Linn.) various parameters such as percentage yield, angle of repose, swelling index, moisture content, density, compressibility index, and solubility were determined.

- Percentage yield

The percentage yield can be calculated from the yield of the reaction. The actual mass which was obtained by the end of the reaction.

- $\quad$ Angle of repose

Funnel method was used to find the angle of repose. When the dried powder was allowed to fall down from the funnel, and the heap was formed, that is known as angle of repose.

- $\quad$ Swelling index

To evaluate the swelling behavior, $1 \mathrm{~g}$ of the seeds of o. tenuiflorum (Linn.) was taken in a $100 \mathrm{~mL}$ measuring cylinder 
with graduated readings in it. Initial volume occupied by seeds was noted. In addition to this, add $2 \mathrm{~mL}$ of alcohol for better dispersion and then add sufficient quantity of water to make up the volume up to $100 \mathrm{~mL}$. The measuring cylinder was kept at a room temperature, and swollen mass of seeds was noted after $24 \mathrm{hrs}$.

- Moisture content

Appropriate quantity of mucilage at $105^{\circ} \mathrm{C}$ was kept for $2 \mathrm{hr}$ in hot air oven. For this measured quantity of drug was kept in a hot air oven and is allowed to lose the moisture content present in it. This would reflect the amount of water present in the raw form of crude drug.

- Density

A pre-sieved and pre-weighed dried mucilage were poured into a graduated cylinder, and the volume covered by mucilage was recorded. The cylinder was tapped until the powder bed volume reached a minimum volume and the tapped volume was recorded.

Exaction of fixed oil of seeds of $O$. tenuiflorum (Linn.)

The Ocimum seeds were crushed and were kept in close contact with petroleum ether in a conical flask for $12 \mathrm{hrs}$. Using electrical shaker, the flask was shaken continuously. Filter out the material and allow it to dry at room temperature for complete evaporation of petroleum ether and oil was collected [39].

Physicochemical evaluation of fixed oil of seeds of $O$. tenuiflorum (Linn.)

Determination of lipid contents

1. Exactly weighed seeds of 0 . tenuiflorum (Linn.) were grounded in mortar and pestle and dried and were kept at room temperature.

2. The extract was added test tube, to this $3 \mathrm{ml}$ of 2:1 mixture (methanol and chloroform) was added. The contents were smashed with a glass rod.

3. Allow them to mix properly using nutator, for 20 minutes.

4. Discard the upper aqueous layer.

5. The organic phase was collected and transferred to the new tube. The contents were dried using nitrogen.

6. The dried residue was dissolved in 1:1 (chloroform and methanol) mixture.

7. The chloroform and methanol solvents were removed, and the percentage yield of the oil was calculated [40].

Estimation of acid value

1. Accurately weighed oil was transferred into $250 \mathrm{ml}$ conical flask.

2. $50 \mathrm{ml}$ of neutralized alcohol solution was added to the oil solution.

3. This mixture was heated for 10 minutes using the heater to dissolve the content.

4. To the above solution, 1-2 drops of phenolphthalein solution were added as an indicator.

5. The above mixture was titrated against the $\mathrm{KOH}$ solution from the burette.

6. At the end point, pink color was appeared [41].

\section{Calculation of acid value}

Volume $(\mathrm{ml})$ of $\mathrm{KOH} \times$
Acid value $=\frac{\text { normality of } \mathrm{KOH} \times \text { equation wt of } \mathrm{KOH}}{\text { Weight of the oil sample }}$

Equivalent weight of $\mathrm{KOH}=56.11$.

\section{Determination of density of oil}

Density is a basic physical property that can be used in correlation with other properties to learn both the light and heavy fractions of petroleum and petroleum products.

To know about the density or relative density of petroleum and its products is important for the conversion of measured volumes to volumes at the standard temperatures of $15^{\circ} \mathrm{C}[42]$.

\section{Principle}

When a small liquid sample was added into an oscillating sample tube and because of change in mass of tube, oscillating frequency gets changed. This was used along with calibration data for determination of density of the sample.

\section{Procedure}

1. Using a suitable syringe, few $\mathrm{mL}$ of sample was poured into the clean, dry sample tube of the digital density analyzer.

2. Sample tube was examined carefully using the illumination light. The tube should be kept free from bubbles and was filled above the suspension point on the right-hand side. The sample should be homogenous in nature.

3. On introduction of the sample into the tube illumination light should be turned off, otherwise, that would affect the measurement temperature.

4. Once the instrument start displaying constant value for density and $\mathrm{t}$-value, the values for both should be recorded.

Determination of saponification value

1. Take $2 \mathrm{~g}$ of sample into a $200 \mathrm{ml}$ conical flask.

2. $25 \mathrm{ml}$ of potassium hydroxide ethanol solution was added to it, and the cooling tube was fixed to it.

3. The flask was heated at a constant temperature with continuous shaking so as to prevent the back flow of ethanol to the cooling tube.

4. After 30 minutes of heating, cool it down and then titrate it with $0.5 \mathrm{~mol} / \mathrm{L} \mathrm{HCl}$.

5. Blank test (without sample following step 1-4 above) should be done 3 times to have a mean value [43].

Antioxidant activity of fixed oil of seeds of $\boldsymbol{O}$. tenuiflorum (Linn.) 2,2-diphenyl-1-picrylhydrazyl (DPPH)

$D P P H$ free radical scavenging activity

Measurement of antioxidant activity of any fixed oil or volatile oil was done in terms of hydrogen donating or ability to scavenge free radical using DPPH method. Mixture was consisting of $2 \mathrm{~mL}$ of oil at different concentration $(100,200,300,400$, and $500 \mu \mathrm{g} / \mathrm{mL})$ and $2 \mathrm{~mL}$ of DPPH $(0.2 \mathrm{mM})$. These were vigorously shaken and incubate them in the dark at a room temperature for 30 minutes. When DPPH from the mixture react with an antioxidant constituent in the oil, that had donated hydrogen, reduction occurs, and that would cause decrease in absorbance at $517 \mathrm{~nm}$ in ultraviolet-visible spectrophotometer. Lower the value, greater was the antioxidant value of the oil [44].

\section{RESULTS}

Macroscopic evaluation of seeds of $\boldsymbol{O}$. tenuiflorum (Linn.)

Results of macroscopic studies of seeds of $O$. tenuiflorum (Linn.) are tabulated in Table 1.

Physicochemical evaluation of seeds of $O$. tenuiflorum (Linn.)

Physicochemical parameters of seeds of $O$. tenuiflorum (Linn.) were determined, and results are shown in Table 2.

Phytochemical screening of seeds of $\boldsymbol{O}$. tenuiflorum (Linn.)

The preliminary phytochemical screening of various extracts, viz., hexane, chloroform, ethyl acetate, and methanol extracts of seeds of o. tenuiflorum (Linn.) was carried out, and results are tabulated in Table 3.

Organoleptic characters of mucilage extracted from seeds of o. tenuiflorum (Linn.)

The results of organoleptic characters of mucilage of seeds of o. tenuiflorum (Linn.) are tabulated in Table 4.

Physicochemical evaluation of mucilage of seeds of $O$. tenuiflorum (Linn.)

The physicochemical parameters of mucilage extracted from seeds of o. tenuiflorum (Linn.) were determined and tabulated in Table 5. 
Extraction of fixed oil from seeds of 0 . tenuiflorum (Linn.)

The fixed oil from crushed seeds of 0 . tenuiflorum (Linn.) was extracted using petroleum ether as solvent. The yield and color of fixed oil are given in Table 6.

\section{Physicochemical evaluation of fixed oil of seeds of 0 . tenuiflorum} (Linn.)

Physicochemical parameters of fixed oil of seeds of 0 . tenuiflorum (Linn.) were determined, and the results are tabulated in Table 7.

Antioxidant activity of fixed oil of seeds of $\boldsymbol{O}$. tenuiflorum (Linn.)

The fixed oil of seeds of $O$. tenuiflorum (Linn.) was evaluated for antioxidant activity by DPPH method, and the results are tabulated in Table 8.

Table 1: Macroscopic evaluation of seeds of o. tenuiflorum (Linn.)

\begin{tabular}{ll}
\hline Parameters & Results \\
\hline Condition & Fresh mature seeds \\
Color & Yellow with small black marks \\
Odor & Aromatic \\
Taste & Mucilaginous \\
Shape & Broadly ellipsoid \\
Size & 1.2 mm long \\
Texture & Nearly smooth \\
\hline
\end{tabular}

Table 2: Physicochemical parameters of seeds of o. tenuiflorum (Linn.)

\begin{tabular}{ll}
\hline Parameter & Results \\
\hline Ash value $(\% \mathrm{w} / \mathrm{w})$ & 8.8 \\
Total ash $(\% \mathrm{w} / \mathrm{w})$ & 0.4 \\
Acid insoluble ash $(\% \mathrm{w} / \mathrm{w})$ & 3.9 \\
Water soluble ash $(\% \mathrm{w} / \mathrm{w})$ & \\
Solvent extractive value $(\% \mathrm{w} / \mathrm{w})$ & 3.6 \\
Water soluble extractive value $(\% \mathrm{w} / \mathrm{w})$ & 2.6 \\
Alcohol soluble extractive value $(\% \mathrm{w} / \mathrm{w})$ & 3.9 \\
Ether soluble extractive value $(\% \mathrm{w} / \mathrm{w})$ & 0.2 \\
Foreign matter $(\% \mathrm{w} / \mathrm{w})$ & 12 \\
Swelling index & 3.3 \\
Moisture content $(\% \mathrm{w} / \mathrm{w})$ & \\
\hline
\end{tabular}

\section{DISCUSSIONS}

The drugs derived from natural resources have a significant contribution in the traditional and modern system of medicines. Relevant steps have been taken by the World Health Organization WHO to carry out the research with the aim of finding new and effective medicinal agents from plants. The development of science of phytopharmaceuticals and the hopes for remedy in chronic diseases generated new enthusiasm in the research work to develop herbal medicines. Plants used in traditional medicines can serve as source of novel therapeutic agents directly or as model compounds for synthetic or semi-synthetic structural modifications.

Various parts of $O$. tenuiflorum (Linn.) (Lamiaceae) are being used traditionally for the treatment of several diseases, except for a few biological studies, not much work has been done to exploit the medicinal properties of $O$. tenuiflorum (Linn.) seeds.

Leaves of this plant are used for antipyretic, analgesic, antioxidant, antibacterial, antifungal, anti-inflammatory, and anticancer activity. Hence, we were interested to submit seeds of this plant to a detailed macroscopic, physicochemical, phytochemical, antioxidant, and anticancer studies.

O. tenuiflorum (Linn.) seeds were purchased from Central Institute of Medicinal and Aromatic Plants, Lucknow, India. The material was identified and authenticated by botanist Dr. Amandeep Kaur Lecture in Botany at S.D. College Barnala. For identification of plant material, macroscopic studies were conducted, and the results are tabulated in Table 1.

In the physicochemical studies, an attempt to standardize $O$. tenuiflorum (Linn.) seeds, several analytical studies were carried out.

Total ash value, acid insoluble ash value, and water soluble ash value were determined and were found to be $8.8 \% \mathrm{w} / \mathrm{w}, 0.4 \% \mathrm{w} / \mathrm{w}$, and $3.9 \% \mathrm{w} / \mathrm{w}$, respectively.

Water soluble extractive value, alcohol soluble extractive value, and ether soluble extractive value were determined and were found to be $3.6 \% \mathrm{w} / \mathrm{w}, 2.6 \% \mathrm{w} / \mathrm{w}$, and $3.9 \% \mathrm{w} / \mathrm{w}$, respectively.

Foreign matter was determined and was found to be $0.2 \% \mathrm{w} / \mathrm{w}$.

Table 3: Preliminary phytochemical screening of seeds of 0 . tenuiflorum (Linn.)

\begin{tabular}{|c|c|c|c|c|c|}
\hline Constituents & Tests & Hexane & Chloroform & Ethyl acetate & Methanol \\
\hline \multirow[t]{3}{*}{ Phytosterols and Triterpenoids } & Salkowaski test & + & - & - & - \\
\hline & Liebermann test & + & - & - & - \\
\hline & Liebermann-Burchard's test & + & - & - & - \\
\hline \multirow[t]{4}{*}{ Alkaloids } & Mayer's test & + & + & + & + \\
\hline & Wagner's test & + & + & + & + \\
\hline & Dragendroff's test & + & + & + & + \\
\hline & Hager's test & + & + & + & + \\
\hline \multirow{2}{*}{ Tannins } & Lead acetate test & - & - & + & + \\
\hline & Potassium dichromate test & - & - & + & + \\
\hline \multirow[t]{3}{*}{ Flavonoids } & Shinoda test & - & - & + & + \\
\hline & Alkaline reagent test & - & - & + & + \\
\hline & Lead acetate test & - & - & + & + \\
\hline \multirow[t]{3}{*}{ Sugar } & Molisch's test & - & - & - & + \\
\hline & Barfoed's test & - & - & - & + \\
\hline & Fehling' solution test & - & - & - & + \\
\hline \multirow{2}{*}{ Protein and Amino acids } & Xanthoproteic test & - & - & - & + \\
\hline & Biuret test & - & - & - & + \\
\hline Saponin & Foam test & - & - & - & - \\
\hline Fats and oil & Grease oil test & + & - & + & + \\
\hline Mucilage & Ruthenium red & - & - & - & + \\
\hline
\end{tabular}

+: Present, -: Absent 
Table 4: Organoleptic character of mucilage extracted from seeds of 0 . tenuiflorum (Linn.)

\begin{tabular}{ll}
\hline Physicochemical parameters & Results \\
\hline Appearance & Amorphous \\
Color & Brown \\
Odor & Odorless \\
Taste & Mucilaginous \\
\hline
\end{tabular}

Table 5: Physicochemical evaluation of mucilage of seeds of o. tenuiflorum (Linn.)

\begin{tabular}{ll}
\hline Physicochemical parameters & Results \\
\hline Percentage yield (\% w/w) & 2.5 \\
Angle of repose & $25^{\circ} 21^{\prime}$ \\
Swelling index & 15.2 \\
Moisture content (\% w/w) & 4.5 \\
Bulk density (g/cc) & 0.3 \\
Tapped density (g/cc) & 0.33 \\
Compressibility index (\%) & 20.56 \\
Solubility & \\
Water & Soluble \\
Acetone & Insoluble \\
Methanol & Insoluble \\
Chloroform & Insoluble \\
Ether & Insoluble \\
Ruthenium red test & Pink color \\
\hline
\end{tabular}

Table 6: Yield and color of fixed oil of seeds of o. tenuiflorum (Linn.)

\begin{tabular}{lll}
\hline Plant material & $\begin{array}{l}\text { Yield of fixed } \\
\text { oil }(\% \mathbf{w} / \mathbf{w})\end{array}$ & Color \\
\hline Seeds of O. tenuiflorum (Linn.) & 08 & $\begin{array}{l}\text { Golden yellow } \\
\text { color }\end{array}$ \\
\hline
\end{tabular}

Table 7: Physicochemical evaluation of fixed oil of seeds of o. tenuiflorum (Linn.)

\begin{tabular}{ll}
\hline Physicochemical parameters & Results \\
\hline Lipid content $(\mathrm{g} / \mathrm{ml})$ & 0.305 \\
Acid value & 123.42 \\
Density of oil $\left(\mathrm{g} / \mathrm{cm}^{3}\right)$ & 0.936 \\
Saponification value & 56.12 \\
\hline
\end{tabular}

Table 8: Antioxidant activity of fixed oil of seeds of o. tenuiflorum (Linn.)

\begin{tabular}{llll}
\hline $\begin{array}{l}\text { Concentration of } \\
\text { Vitamin } \mathbf{C}(\boldsymbol{\mu g} / \mathbf{m l})\end{array}$ & $\begin{array}{l}\text { \% of } \\
\text { inhibition }\end{array}$ & $\begin{array}{l}\text { Concentration of } \\
\text { fixed oil }(\boldsymbol{\mu g} / \mathbf{m l})\end{array}$ & $\begin{array}{l}\% \text { of } \\
\text { inhibition }\end{array}$ \\
\hline 100 & 89.4 & 100 & 82.1 \\
200 & 91.5 & 200 & 83.4 \\
300 & 94.3 & 300 & 86.6 \\
400 & 96.6 & 400 & 89.1 \\
500 & 97.2 & 500 & 93.2 \\
\hline
\end{tabular}

The moisture content in the seeds was determined by dry heat method in the oven and was found to be $3.3 \% \mathrm{w} / \mathrm{w}$.

Swelling index was determined and was found to be 12 .

For phytochemical screening, various extracts, viz., hexane, chloroform, ethyl acetate, and methanol were prepared by successive Soxhelation process, and the extracts were subjected to various chemical tests to detect the presence of various classes of phytoconstituents. The results revealed the presence of carbohydrates, proteins, amino acids, phenols, tannins, phytosterols, triterpenoids, alkaloids, flavonoids, fixed oils, and mucilage in 0 . tenuiflorum (Linn.) seeds. The results are shown in Table 3.

O. tenuiflorum (Linn.) seed mucilage was isolated, and percentage yield was determined.

The organoleptic characters of mucilage of 0 . tenuiflorum (Linn.) seeds were determined. The obtained mucilage was an amorphous brown powder with mucilaginous taste. No characteristic odor was observed in the mucilage.

The physicochemical characters of mucilage of 0 . tenuiflorum (Linn.) were determined, and the results are given in Table 5.

The percentage yield was found to be 2.5. The angle of repose was determined and was found to be $25^{\circ} 21^{\prime}$. Mucilage was found to have good swelling potential with swelling index 12 . The moisture content, bulk density, tapped density, and compressibility index of mucilage were determined and were found to be $4.5,0.3,0.33$, and 20.56 , respectively. The mucilage was found to be soluble in water and insoluble in ether, acetone, methanol, and chloroform. The results indicate that the obtained mucilage has good flow properties.

The fixed oil from the seeds of 0 . tenuiflorum (Linn.) was extracted with light petroleum ether $\left(40-60^{\circ} \mathrm{C}\right)$, with the help of electrical shaker for about $12 \mathrm{hrs}$ and the solvent was removed by rotary vacuum evaporator, $08 \% \mathrm{w} / \mathrm{w}$ golden yellow oil was obtained. The fixed oil evaluated for physicochemical properties.

Lipid content, acid value, density, and saponification value of the oil were determined, and the results are shown in Table 7.

Antioxidant activity of fixed oil of 0 . tenuiflorum (Linn.) seeds was evaluated by DPPH method. DPPH radical scavenging activity assay assessed the ability of the extracted oil to donate hydrogen or to scavenge free radical. DPPH radical is a stable free radical, and when it reacts with an antioxidant compound, which can donate hydrogen, it is reduced to di-phenyl acryl hydrazine. The change in color (i.e., from deep violet to light yellow) is measured spectrophotometrically.

The fixed oil, when mixed with DPPH, decolorized the color of DPPH solution due to hydrogen donating ability. Results revealed that fixed oil has strong antioxidant activity at all concentrations from 100 to $500 \mu \mathrm{g} / \mathrm{ml}$, the results are shown in Table 8 .

\section{CONCLUSION}

In this study, pharmacogonostical, physiochemical properties of mucilage, physicochemical properties, antioxidant, and anticancer activities of fixed oil of seeds of 0 . tenuiflorum (Linn.) were carried out, and from this study, the following conclusions can be made.

In pharmacogonostical studies, an analytical parameter such as ash values, extractive values, moisture content, and swelling index of o. tenuiflorum (Linn.) seeds was determined; these studies will be helpful for identification of the plant material. Various extract of o. tenuiflorum (Linn.) seeds, viz., hexane, ethyl acetate, chloroform, and methanol extracts were prepared and were subjected to phytochemical screening. The studies revealed the presence of phytosterols and triterpenoids, alkaloids, tannins, flavonoids, sugar, protein, amino acid, fat, and oils.

The mucilage from 0 . tenuiflorum (Linn.) seeds was extracted and the physicochemical parameters, viz., color, taste, odor, percentage yield, swelling index, density, compressibility index, and solubility of the extracted mucilage were determined. The various physicochemical properties show the ability of the mucilage as disintegrating and binding agent tablets. However, further study is required to establish 
the mucilage of $O$. tenuiflorum (Linn.) seeds as an excipient in pharmaceutical formulations.

The extracted oil from crushed seeds using petroleum ether as a solvent was subjected for physicochemical evaluation. Lipid content, acid value, density of oil, and saponification value of fixed oil were determined. These physicochemical studies will help for the standardization and identification of fixed oil.

The antioxidant activity of the oil was estimated by DPPH method and the results that come out reveals that the fixed oil possesses the potent antioxidant activity.

The findings of the present work indicate that the mucilage of o. tenuiflorum (Linn.) seeds may be established as an excipient to prepare various formulations, and fixed oil has demonstrated significant antioxidant activity. However, further studies are required so that oil may be established as antioxidant drug.

\section{REFERENCES}

1. Farnsworth NR, Morris RW. Higher plants-the sleeping giant of drug development. Am J Pharm Sci Support Public Health 1976;148(2):46-52.

2. De Smet PA. The role of plant-derived drugs and herbal medicines in healthcare. Drugs 1997:54(6):801-40.

3. Quick J, Zhang X, Kasilo O, D'Alessio R, Land S, Graaff P, et al. WHO Policy Perspectives on Medicines-Traditional Medicine-Growing Needs and Potential. A. MPHT a. P. Cluster. Geneva: WHO; 2002. p. 1-6.

4. Ghosh GR. Tulasi (NO Labiatae, genus-Ocimum). N Approaches Med Health 1995;3:23-9.

5. Simpson BB, Conner OM. Economic Botany Plants in Our World. Hamburg: McGraw Hill Book Company; 1986. p. 640.

6. Sanda K, Koba K, Nambo P, Gaset A. Chemical investigation of Ocimum species growing in Togo. Flavour Fragr J 1998;13(4):226-32.

7. Singh S, Taneja M, Majumdar DK. Biological activities of Ocimum sanctum L. Fixed oil-an overview. Indian J Exp Biol 2007;45(5):403-12.

8. Naquvi KJ, Dohare SL, Shuaib M, Ahmad MI. Chemical composition of volatile oil of Ocimum sanctum Linn. Int J Biomed Adv Res 2012;3(2):129-31.

9. Vani SR, Cheng SF, Chuah $\mathrm{CH}$. Comparative study of volatile compounds from genus Ocimum. Am J Appl Sci 2009;6(3):523.

10. Khan A, Ahmad A, Akhtar F, Yousuf S, Xess I, Khan LA, et al. Ocimum sanctum essential oil and its active principles exert their antifungal activity by disrupting ergosterol biosynthesis and membrane integrity. Res Microbiol 2010;161(10):816-23.

11. Anbarasu K, Vijayalakshmi G. Improved shelf life of protein-rich tofu using Ocimum sanctum (Tulsi) extracts to benefit Indian rural population. J Food Sci 2007;72(8):M300-5.

12. Mondal S, Mirdha BR, Mahapatra SC. The science behind sacredness of Tulsi (Ocimum sanctum Linn.). Indian J Physiol Pharmacol 2009;53(4):291-306.

13. Aguiyi JC, Obi CI, Gang SS, Igweh AC. Hypoglycaemic activity of Ocimum gratissimum in rats. Fitoterapia 2000;71(4):444-6.

14. Interaminense LF, Jucá DM, Magalhães PJ, Leal-Cardoso JH, Duarte GP, Lahlou S. Pharmacological evidence of calcium-channel blockade by essential oil of Ocimum gratissimum and its main constituent, eugenol, in isolated aortic rings from DOCA-salt hypertensive rats. Fundam Clin Pharmacol 2007;21(5):497-506.

15. Freire CM, Marques MO, Costa M. Effects of seasonal variation on the central nervous system activity of Ocimum gratissimum L. Essential oil. J Ethnopharmacol 2006;105(1-2):161-6.

16. Ifesan BO, Ijarotimi OS, Oshundahunshi OF. Evaluation of the antioxidant activity of Ocimum sp. J Food Technol 2006;4(4):318-21.

17. Pessoa LM, Morais SM, Bevilaqua CM, Luciano JH. Anthelmintic activity of essential oil of Ocimum gratissimum Linn. And eugenol against Haemonchus contortus. Vet Parasitol 2002;109(1-2):59-63.

18. Madeira SV, Matos FJ, Leal-Cardoso JH, Criddle DN. Relaxant effects of the essential oil of Ocimum gratissimum on isolated ileum of the guinea pig. J Ethnopharmacol 2002;81(2):1-4.

19. Mishra P, Mishra S. Study of antibacterial activity of Ocimum sanctum extract against gram positive and gram negative bacteria. Am J Food Technol 2011;6(4):336-41.

20. Monga J, Sharma M, Tailor N, Ganesh N. Antimelanoma and radioprotective activity of alcoholic aqueous extract of different species of Ocimum in C(57)BL mice. Pharm Biol 2011;49(4):428-36.

21. Jeeva S, Sukumaran S, Joselin J, Geetha VS. Phytochemical and antimicrobial study of the flowers of Tulsi an endemic palm of Southern Western Ghats. Med Aromat Plants 2015;4:181

22. Prakash P, Gupta N. Therapeutic uses of Ocimum sanctum Linn (Tulsi) with a note on eugenol and its pharmacological actions: A short review. Indian J Physiol Pharmacol 2005;49(2):125-31.

23. Sharma KR. Solar aided combined cycle power plant. J Laser Opt Photonics 2014;1:e103.

24. Singh V, Verma O. Ocimum sanctum (Tulsi): Bio-pharmacological activities. Pharmacology 2010;1(10):WMC001046.

25. Otto WJ, Holówko WH, Krawczyk MS, Król MA, Wilkowojska UM, Sierdzinski $\mathrm{J}$, et al. Hcc angiogenic propriety and tumor recurrence in liver transplant recipients. Pharm Anal Acta 2015;6:343.

26. Kabir Dar A, Siddiqui MA, Wahid-Ul H, Lone AH, Manzoor N, Haji A. Threat status of rheum emodi-a study in selected cis-himalayan regions of Kashmir valley Jammu and Kashmir India. Med Aromat Plants 2015;4(183):2167-412.

27. Geeta, Vasudevan DM, Kedlaya R, Deepa S, Ballal M. Activity of Ocimum sanctum (the traditional Indian medicinal plant) against the enteric pathogens. Indian J Med Sci 2001;55(8):434-8, 472.

28. Eddouks M, Hebi M, Zeggwagh N, El-Bouhali B, Hajji LH. Effect of Momordica charantia, Camellia sinensis and Cinnamon species on insulin resistance. Med Aromat Plants 2015;4(182):2167-412.

29. Rehman HU. In vitro propagation of Kainth (Pyrus pashia) using explants from forced cutting. J Hortic 2015;127:1-6.

30. Ciurea SO, Kongtim P, Rondon G, Chen J, Tomuleasa C, Konopleva M, et al. Should a more personalized approach be applied to hematopoietic stem-cell transplantation? J Stem Cell Res Ther 2015;5:272.

31. Joseph BA, Nair VM. Ocimum sanctum Linn. (Holy basil): Pharmacology behind its anti-cancerous effect. Int J Pharm Bio Sci 2013;4(2):556-75

32. Chanda S, Nagani K. In vitro and in vivo methods for anticancer activity evaluation and some Indian medicinal plants possessing anticancer properties: An overview. J Pharmacogn Phytochem 2013;2(2):2856.

33. Symons MC, Gutteridge JM. Free Radicals and Iron: Chemistry, Biology, and Medicine. Oxford, UK: Oxford University Press; 1998.

34. Halliwell B, Aruoma OI. DNA damage by oxygen-derived species. Its mechanism and measurement in mammalian systems. FEBS Lett 1991;281(1-2):9-19.

35. Kokate CK, Purohit AP, Gokhle SB. Textbook of Pharmacognosy. Pune: Nirali Prakashan; 2001. p. 533-7.

36. Ansari SH. Essentials of Pharmacognosy. $1^{\text {st }}$ ed., Vol. 576. New Delhi: Birlia Publication; 2005. p. 580-1.

37. Mukherjee PK. Quality Control of Herbal Drugs. $1^{\text {st }}$ ed. New Delhi: Business Horizons; 2002. p. 110048.

38. Trease GE, Evan WC. Textbook of Pharmacognosy. London: Balliere Tindall; 1985.

39. Sharma VK, Tiwari M, Chauhan NS, Nema RK. Phytochemical investigation on the ethanolic extract on the leaves of Zizyphus xylopyrus (Retz.) Willd. Int J Agron Plant Prod 2012;3(1):26-37.

40. Bligh EG, Dyer WJ. A rapid method of total lipid extraction and purification. Can J Biochem Physiol 1959;37(8):911-7.

41. European Committee for Standardization. European Standard EN14104. Acid Value was Determined by Tritrimetry Method. Brussels, Belgium: European Committee for Standardization; 2003.

42. Hookey GJ. Standard Test method for Density and Relative density of liquids by digital Density Meter.

43. Brandariz I, Barriada JL, Vilarino T, de Vicente ME. Comparison of several calibration procedures for glass electrodes in proton concentration. Monatsh Chem Chem Mon 2004;135(12):1475-88.

44. Hae-Ryong P. Protective effects of Paeonia Lactiflora Pall on Hydrogen Peroxide-induced Apoptosis in PC12 cells. Afr J Biotechnol 2006;5(23):2388-96. 